\title{
Türkiye'de Faaliyet Gösteren Katılım Bankalarının Entropi ve WASPAS Yöntemleri ile Performans Analizi
}

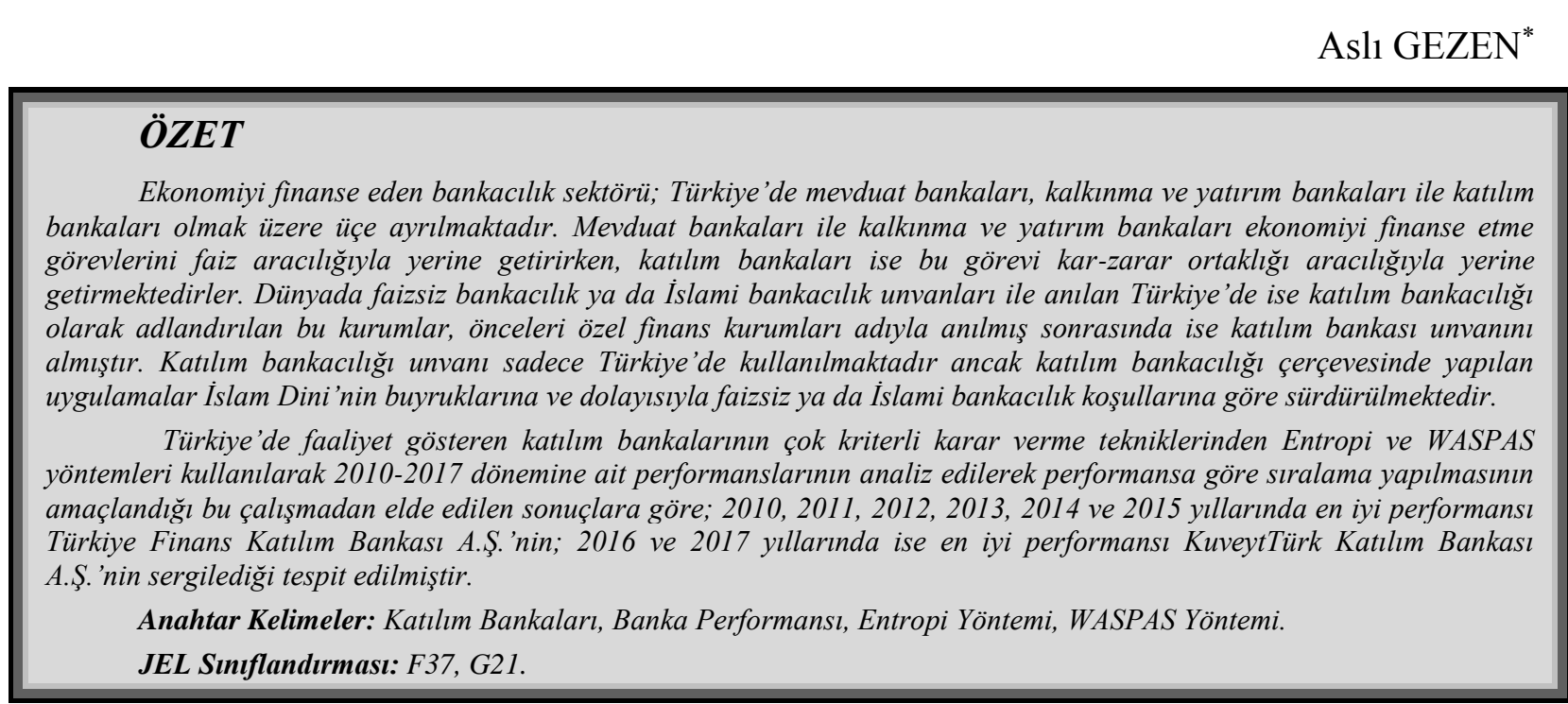

\begin{abstract}
Performance Analysis of Participation Banks Operating in Turkey by Entropy and WASPAS Methods

\section{ABSTRACT}

The banking sector, which finances the economy, is divided into three categories as deposit banks, development and investment banks and participation banks in Turkey. While deposit banks and development and investment banks carry out their duty of financing the economy through interest, participation banks perform this task through profit-loss partnership. Referred to by the titles of interest-free banking or Islamic banking institutions in the world and called as participation banking in Turkey, previously these institutions were known as private financial institutions before the name has taken the title of participation banks. Participation banking title is used only in Turkey but the practices carried out within the framework of participation banking are carried out according to the orders of Islamic religion and hence interest-free or Islamic banking conditions.

In this study, the performances of participation banks in Turkey for the period of 2010-2017 were analized by using multi-criteria decision making techniques using Entropy and WASPAS methods and sorted according to their performance. According to these results, it has been determined that the best performance for the years of 2010, 2011, 2012, 2013, 2014 and 2015 was Turkiye Finans Participation Bank Inc., while it was KuveytTurk Participation Bank Inc. for the years of 2016 and 2017.
\end{abstract}

Keywords: Participation Banks, Bank Performance, Entropy Method, WASPAS Method.

Jel Classification: F37, G21.

Makale Gönderim Tarihi: 31.01.2019

Makale Kabul Tarihi: 24.03.2019

Makale Türü: Araştırma makalesi

\footnotetext{
* Öğr. Gör., Çanakkale Onsekiz Mart Üniversitesi, Gelibolu Piri Reis Meslek Yüksekokulu, asligezen@comu.edu.tr, Orcid ID: 0000-0002-4001-9852.
} 


\section{GİRIŞ}

Katılım bankacılığı; oranı önceden belirlenmiş faiz karşılığında toplanan mevduatların bankanın belirlediği faiz oranı üzerinden fon ihtiyacı olanlara kredi şeklinde kullandırılmasını temel alan geleneksel bankacılığın aksine faiz yerine kar-zarar ortaklığı ile katılım payı sağlayarak katılımcıların faaliyet sonuçlarına katılmasını sağlamayı temel almaktadır. Böylece; tasarruflarını kullandırmaları karşılığında faiz almak istemeyen tasarruf sahiplerinin sermaye birikimleri de ekonomiye kazandırılmaktadır (Özulucan ve Deran, 2006: 87).

Kur'an-1 Kerim ve Sünnette faiz, İslam hukukunun temel yasaklarından biridir. Arapçası "riba" olan faiz, "artış, aşırıcılık, gelişme" gibi anlamlara gelmektedir. İslamiyet kesin ve keskin bir dille faizi yasaklarken, ticareti serbest bırakmış ve ticaret hem helal kılınmış hem de teşvik edilmiştir (Pehlivan, 2016: 299). İslami inanışa göre karşılığı olmayan bir mal kazancı olarak kabul edilen faiz, insanlardaki erdem duygularını köreltmekte, toplumsal yardımlaşmayı felce uğratmakta, insanları ticaret, zanaat ve ziraat gibi iktisadi hayatın temeli olan faaliyetlerden alıkoymakta, genellikle borç verenleri zengin, alanları ise yoksul hale getirerek sınıfsal çatışmayı arttırmakta, borçluların bireysel özgürlüklerini sınırlamakta ve daraltmaktadır (Kalaycı, 2013: 52). İslam dininde faizin yasaklanmış olması, Müslümanların önemli bir kısmının, faizli işlemlerden kaçınmasına ve dolayısıyla geleneksel bankalarla çalışma konusunda isteksiz olmasına neden olmaktadır (Ergeç vd., 2014: 54). Katılım bankacılı̆̆ uygulandığı bir sistemdir ve faizin İslam dinine göre haram olarak kabul edilmesi nedeniyle, alternatif bir finans aracı olarak kabul edilmiştir (Arslan, 2017: 2). Katılım bankaları da bu nedene dayalı olarak ortaya çıkan ve kar-zarar esasına göre çalışan ve bankacılık fonksiyonlarını İslami kurallara göre yerine getiren bankalardır. Katılım bankaları, faizin İslam dinine göre yasak olması nedeniyle, tasarruflarını geleneksel bankalara yatırmak istemeyen halkın sahip oldukları tasarrufları İslami prensipler çerçevesinde ekonomiye dahil ederek, kalkınmayı sağlayacak yatırımlara dönüştürülmesi işlevini yerine getiren kuruluşlardır (Pehlivan, 2016: 299). Katılım bankaları, mali sektörde faiz dışı prensiplere göre çalışarak bu prensiplere uygun şekilde her türlü bankacılık faaliyetini yerine getirmektedirler (Arslan, 2017: 2).

Katılım bankalarını, tasarruflarını kullandırmaları karşılığında faiz almak istemediği için tasarruflarını bankalara yatırmayıp altın, döviz, bina, arsa seklinde değerlendiren tasarruf sahiplerinin, tasarruflarının üretim sürecine sokulması amacıyla kurulan ve kar-zarar ortaklığı anlayışıyla faaliyette bulunan kurumlar şeklinde de tanımlamak mümkündür (Özulucan ve Deran, 2006: 87). Katılım bankacılığını, parasal işlemlerle mal ve hizmet hareketlerinin birbirine sıkı sıkıya bağlandığ geldiği; gelirin ise, katılım hesabı sahipleriyle kar ve zarar ortaklığı esasına göre bölüşüldüğü bir sistem olarak da tanımlamak mümkündür (Erol ve Güneş, 2016: 96). Faizsiz esasa göre çalışan katılım bankaları, kar ve zarara katılma esasına göre fon toplayıp; ticaret, ortaklık ve finansal kiralama yöntemleriyle fon kullandıran bir bankacılık türüdür (Esmer ve Bağcı, 2016: 18). Katılım hesapları ise, katılım bankalarında açılan ve sahibine kar veya zarar getiren vadeli yatırım hesaplarıdır. Katılım bankaları, katılım hesaplarındaki fonları iktisadi faaliyetlerde değerlendirerek ticari kazanç elde etmeye çalışır ve kazanç gerçekleşirse, gerçekleşen kazancı ortağı durumundaki katılım hesabı sahipleriyle paylaşırlar (Erol ve Güneş, 2016: 96). 
Türkiye'de faizsiz bankacılığın geçmişi 1970'lere kadar uzanmaktadır. Bu amaçla ilk kez 1975 yılında Devlet Sanayi ve İşçi Yatırım Bankası kurulmuştur. Ancak 1978'den itibaren geleneksel bankalar gibi çalıştığ 1 için başarısız olmuştur. Bu başarısız deneyimden sonra 1983 yılında bu konu tekrar ele alınmış ve 16 Aralık 1983 tarihli 83/7506 sayılı Bakanlar Kurulu Kararnamesi ile faizsiz bankaların Türkiye'de faaliyet göstermelerine izin verilmiştir. Bu kurumlara Özel Finans Kurumları adı verilmiştir. Bu kurumların statüleri ve unvanları 19 Ekim 2005 tarihli ve 5411 sayılı yeni Bankalar Kanunu ile Katılım Bankası'na dönüştürülmüştür (Esmer ve Bağc1, 2016: 19). Ocak 2019 itibariyle Türkiye'de; Albaraka Türk Katılım Bankası A.Ş., KuveytTürk Katılım Bankası A.Ş., Türkiye Finans Katılım Bankası A.Ş., Vakıf Katılım Bankası A.Ș. ve Ziraat Katılım Bankası A.Ş. olmak üzere 5 katılım bankası faaliyet göstermektedir. Türkiye'deki tüm katılım bankaları Türkiye Katılım Bankaları Birliği (TKBB) üyesidir.

Çalışmada Türkiye'de faaliyet gösteren katılım bankalarının performanslarının analizinin yapılması amaçlanmıştır. Bu amaç doğrultusunda önce çok kriterli karar verme tekniklerinden Entropi yöntemi kullanılarak; toplam aktifler, kredi büyüklükleri, özsermaye büyüklüğü, ödenmiş sermaye, şube sayısı ve çalışan sayısı kriterlerinin ağırlıkları tespit edilmiştir. Kriterlerin ağırlıkları tespit edildikten sonra WASPAS yöntemi ile Türkiye'de faaliyet gösteren katılım bankalarının performans sıralaması yapılmıştır. Çalışmanın ilerleyen bölümlerinde literatür taramasına, yönteme, analizlere, sonuç ve önerilere yer verilmiştir.

\section{LITERATÜR TARAMASI}

Literatür incelendiğinde Entropi ve WASPAS yöntemlerinin bir arada kullanıldığ çalışmaların sayısının çok az olduğu görülmektedir. Bu iki yöntemi bir arada kullanarak yapılan çalışmalardan ulaşılabilir durumdakiler aşağıda özetlenerek sıralanmıştır.

Karaca ve Ulutaş (2018) tarafından yapılan çalışmada, Türkiye için en uygun enerji kaynağının belirlenmesi amaçlanmıştır. Bu amaç doğrultusunda Entropi yöntemi aracılığıyla enerji kaynaklarına ait kriterlerin ağırlıkları tespit edilmiş ve WASPAS yöntemiyle Türkiye'de enerji ihtiyacının karşılanmasında uygun yenilenebilir enerji kaynağının hangisi olabileceği yönünde öneri getirilmiştir. Analizlerden elde edilen sonuçlara göre; Türkiye için yatırım yapılabilecek en uygun yenilenebilir enerji kaynak sıralamasının Hidro, Jeotermal, Rüzgâr, Biyokütle ve Güneş enerjisi olduğu saptanmıştır.

Ural vd. (2018) tarafından yapılan çalışmada, Entropi ve WASPAS yöntemleri kullanılarak Türkiye'de faaliyet gösteren kamu bankalarının 2012-2016 yıllarına ait performanslarının analiz edilmesi ve ortaya koyulması amaçlanmıştır. Bu amaç doğrultusunda; kriter ağırlıkları Entropi yöntemi ile belirlendikten sonra WASPAS yöntemi ile performans sıralaması yapılmıştır. Analizler sonucunda; 2012 ve 2013 yıllarında en iyi performansı Türkiye Vakıflar Bankası T.A.O.'nun; 2014, 2015 ve 2016 yıllarında ise en iyi performansı Türkiye Cumhuriyeti Ziraat Bankası A.Ş.'nin gösterdiği tespit edilmiştir.

Akçakanat vd. (2017) aktif büyüklüklerine göre küçük, orta ve büyük ölçekli bankaların performanslarını Entropi ve WASPAS yöntemleri ile değerlendirmeyi amaçladıkları çalışmalarında, Bankalar Raporu 2016 ve Türkiye Bankalar Birliği'nin 2016Q3 verilerinden yararlanmışlardır. Entropi yöntemi aracılığıyla kriter ağırlıkları belirlendikten sonra WASPAS yöntemi ile bankaların performanslarına göre sıralaması yapılmıştır. Büyük 
ölçekli bankalarda birinci sırayı Türkiye Cumhuriyeti Ziraat Bankası A.Ş.'nin; orta ölçekli bankalarda birinci sırayı Finansbank A.Ş.'nin ve küçük ölçekli bankalarda birinci sırayı Anadolubank A.Ş.'nin aldığı saptanmıştır.

Ayyıldız ve Murat (2017) yaptıkları çalışmada, Türkiye'nin 81 ilinin eğitim performanslarını belirlemeyi amaçlamışlardır. $\mathrm{Bu}$ amaç doğrultusunda Entropi yöntemi aracılığıyla kriterler belirlenmiş ve WASPAS yöntemi aracilığıyla illerin performans sıralaması yapılmıştır. Çalışmanın sonucunda, nüfusu daha az olan şehirlerin nüfusu daha çok olan şehirlere oranla daha iyi bir performans sergilediği tespit edilmiştir.

Ghorabaee vd. (2016) tarafından yapılan çalışmada, Entropi ve WASPAS yöntemleri kullanılarak yeşil tedarik zinciri yönteminin tedarik zincirinin tüm faaliyetlerine ve aşamalarına etkilerinin ortaya koyulması amaçlanmıştır. Entropi yöntemi aracılığıyla çevresel kriterlerin ağırlıkları belirlenmiştir. Sonrasında WASPAS yöntemi ile kriterlerin birbirinden farklı olan öznel ve nesnel ağırlıklarını birleştirilmiştir. Belirlenen kriterlerin verimlilik ve istikrar açısından birbirleriyle uyumlu oldukları sonucuna ulaşılmıştır.

Bagocius vd. (2013) Klaipeda bölgesinde ekonomik ihtiyaçları karşılamak için Klaipeda limanının geliştirmeye yönelik bütünleşik karar verme kombinasyonu oluşturmayı amaçlamışlardır. Çalışmada; limanın geliştirilmesi ile ilgili 12 kriter belirlenmiş ve belirlenen kriterlerin önem dereceleri entropi yöntemi ile ağırlıklandırılmıştır. Ağırlıklandırılan kriterlerden 4 tanesinin performans değerleri ise WASPAS yöntemi kullanılarak ölçülmüştür. Yapılan analizler sonucunda, sorunu çözmek için önerilen modele göre en iyi alternatifin dördüncü alternatif olduğu tespit edilmiştir.

Dejus ve Antucheviciene (2013) tarafından yapılan çalışmada; şantiyelerde gerçekleşen meslek kazalarının nedenleri ve olası kazaları önleyici tedbirleri ele almak amaçlanmıştır. $\mathrm{Bu}$ doğrultuda çalışmada inşaat işçileri için sağlık ve güvenlik eğitimi (öğrenme) üzerine tartışmalar sunulmuş, gerçek inşaat kazaları ve sebepleri incelenmiştir. Çalışmada bir dizi tipik iş güvenliği çözümünün güçlü ve zayıf yönleri değerlendirilmesi ve bu kriterlerin nispi öneminin belirlenmesi için entropi yöntemi ile WASPAS yöntemi uygulanmıştır. Yapılan analizler sonucunda şantiye alanındaki kazaların güvenlik ile ilgili eğitimlerin yetersizliğinden kaynaklandığı tespit edilmiştir. Baz alınan asansör boşluğu ile ilgili kazaların önlenebilmesi amacıyla altı çözüm önerilmiş ve bu çözümlerin gerçek yaşam durumlarında kullanılabilirliği ile ilgili sıralama WASPAS yöntemi aracılığıyla yapılmıştır.

\section{YÖNTEM VE ANALIZZ}

Bu çalışmada Türkiye'de faaliyet gösteren katılım bankalarının 2010, 2011, 2012, 2013, 2014, 2015, 2016 ve 2017 yıllarındaki performans analizlerini yaparak bankaların yıllar itibariyle performanslarına göre sıralanması ve belirtilen yıllar itibariyle performansı en yüksek katılım bankasının saptanması amaçlanmıştır. Bu amaç doğrultusunda kullanılan yöntemlere, analiz sonuçlarına ve bulgulara aşağıda ayrıntılı olarak yer verilmiştir.

\subsection{Araştırmanın Yöntemi}

Türkiye'de faaliyet gösteren katılım bankalarının performans sıralamalarını belirleyebilmek için; öncelikle kriter ağırlıklarının hesaplanabilmesi amacıyla Entropi 
yöntemi, daha sonra ise sıralamayı yapabilmek amacıyla WASPAS yöntemi kullanılmıştır. Aşağıda Entropi ve WASPAS yöntemlerine ilişin bilgiler yer almaktadır.

\subsubsection{Entropi Yöntemi}

Entropi kavramı ilk kez Rudolph Clausius (1865) tarafından sistem içerisindeki kaosun tanımlanması amacıyla kullanılmış ve sistemdeki kaosun bir ölçüsü olarak tanımlanmıştır. Shannon (1948) tarafından ise bilgi teknolojilerine uyarlanmak amaciyla geliştirilmiştir (Akçakanat vd., 2017: 290; Ural vd., 2018: 131). 2009 yılına gelindiğinde ise, Wang ve Lee tarafından bir ağırlık hesaplama yöntemi olarak geliştirilmiş ve kullanılmaya başlanmıştır (Ömürbek ve Aksoy, 2016: 728). Yöntemin en önemli niteliği bir yapının bütününe uygulanabildiği gibi siluet bütününe kadar da çeşitli ölçeklerde uygulanabilmesidir ve yöntem nesnel bir nitelik taşımaktadır (Akçakanat vd., 2017: 290; Ural vd., 2018: 131).

Entropi yöntemi 5 aşamadan oluşmaktadır (Ömürbek ve Aksoy, 2016: 728; Akçakanat vd., 2017: 290; Ural vd., 2018: 131):

1. Aşama: Karar matrisi oluşturulur. Karar matrisinin normalizasyonu fayda ve maliyet indekslerine göre denklem (1) ve denklem (2) aracılığıyla hesaplanır.

$$
\begin{aligned}
& r_{i j}=\left\{x_{i j} \mid \max _{i j}\right\}\left(i=1 \ldots \ldots m_{;} J=1 \ldots \ldots n\right) \\
& r_{i j}=\left\{x_{i j} \mid \min _{i j}\right\}\left(i=1 \ldots \ldots m_{;} J=1 \ldots \ldots n\right)
\end{aligned}
$$

2. Aşama: Farklı ölçü birimlerindeki aykırılıkları yok etmek için normalizasyon işlemi yapılarak $\mathbf{P}_{\mathbf{i j}}$ değeri denklem (3) aracılığıyla hesaplanır.

$P_{i j}=\frac{a_{i j}}{\sum_{i=1}^{m} a_{i j}} ; \forall_{j}$

$\dot{\mathrm{I}}=$ alternatifler

$\mathrm{j}=$ kriterler

$\mathrm{P}_{\mathrm{ij}}=$ normalize edilmiş değerler

3. Aşama: $\mathbf{E}_{\mathbf{j}}$ 'nin entropisi denklem (4) aracılığıyla hesaplanır.

$$
E_{j}=-k \sum_{i=1}^{m}\left[P_{i j} \ln P_{i j}\right] ; \forall_{j}
$$

$\mathrm{k}=(\ln (\mathrm{n}))^{(-1)}$

$\mathrm{k}=$ Entropi katsayıs1

$\mathrm{E}_{\mathrm{j}}=$ Entropi değeri 
$\mathrm{P}_{\mathrm{ij}}=$ normalize edilmiş değerler

4. Aşama: $\mathrm{d}_{\mathrm{j}}$ belirsizliği denklem (5) aracılığıyla hesaplanır.

$d_{j}=1-E_{j} ; \forall_{\mathrm{j}}$

5. Aşama: j kriterinin önem derecesinin belirlenmesi için $\mathbf{w}_{\mathbf{j}}$ ağırlık değerleri yani entropi kriter ağırlıkları denklem (6) aracılığıyla hesaplanır.

$$
w_{j}=\frac{d_{j}}{\sum_{j=1}^{n} d_{j}} ; \forall_{j}
$$

\subsubsection{WASPAS Yöntemi}

WASPAS yöntemi ilk kez Zavadskas vd. (2012) tarafindan geliştirilmiştir. Yöntem; WSM (Weighted Sum Model) Ağırlıklı Toplam Model ve WPM (Weighted Product Model) Ağırlıklı Çarpım Modelinin kombinasyonundan oluşmakta ve sıralama doğruluğunu artırmayı amaçlamaktadır (Akçakanat vd., 2017: 290; Ural vd., 2018: 132).

WASPAS yöntemi 6 aşamadan oluşmaktadır (Akçakanat vd., 2017: 290-292; Ural vd., 2018: 132-133):

1. Aşama: Karar matrisi oluşturulur. Denklem (7)'de m aday alternatiflerin sayısını; $\mathrm{n}$ ise değerlendirme kriterleri sayısını göstermektedir. $x_{i j}$, j'inci kriter göz önüne alınarak i'inci alternatifin performansidir.

$$
x=\left[\begin{array}{cccc}
x_{11} & x_{12} & \cdots & x_{1 n} \\
x_{21} & x_{22} & \cdots & x_{2 n} \\
\vdots & \vdots & \vdots & \vdots \\
x_{m 1} & x_{m 1} & \cdots & x_{m n}
\end{array}\right]
$$

2. Aşama: Fayda kriterleri için denklem (8), maliyet kriterleri için denklem 9 aracılığıyla normalize edilmiş karar matrisi oluşturulur. Burada $x_{i j}$ değeri $x_{i j}$ değerinin normalize edilmiş halidir.

$$
\begin{aligned}
& \bar{x}_{i j}=x_{i j} / \max _{i} x_{i j} \\
& \bar{x}_{i j}=\min _{i} x_{i j} / x_{i j}
\end{aligned}
$$

3. Aşama: WSM'ye dayalı i. alternatifin toplam nispi önemi hesaplanır. Bu aşamada, iki eşitlik kriteri temel alınarak, bir eşzamanlı iyimserlik kriteri aranmaktadır. Toplam nispi değer önemi i'inci alternatif değeri her bir kritere ait ağırlık değeri ile çarpılır ve daha sonra her bir alternatif değeri sırasıyla toplanarak denklem (10)'daki gibi hesaplanır. 


$$
Q_{i}^{(1)}=\sum_{j=1}^{n} \bar{x}_{i j} \cdot w_{j}
$$

4. Aşama: WPM'ye dayalı i. alternatifin toplam nispi öneminin hesaplanır. $\mathrm{Bu}$ aşamada, toplam göreceli önemlilik değerleri denklem (11) aracılığıyla hesaplanır. Normalize edilmiş karar matrisi üzerinden her bir i.alternatif kriterinin değeri için ilgili kriter ağırlığının kuvveti alınır ve bulunan değerler her bir alternatif için sırasıyla çarpılarak $Q_{i}^{(2)}$ değeri hesaplanır.

$$
Q_{i}^{(2)}=\prod_{j=1}^{n}\left(\bar{x}_{i j}\right)^{w_{j}}
$$

5. Aşama: Toplamsal ve çarpımsal metodların ağırlıklandırılmış ortak genel kriter değeri hesaplanır. Ağırlıklı Toplam ve Ağırlıklı Çarpım Modelleri için ağırlıklandırılmış ortak genel kriter değeri denklem (12) aracılığıyla hesaplanmaktadır.

$$
Q_{i}=0.5 Q_{i}^{(1)}+0.5 Q_{i}^{(2)}=0.5 \sum_{j=1}^{n} \bar{x}_{i j} \cdot w_{j}+0.5 \prod_{j=1}^{n}\left(\bar{x}_{i j}\right)^{w_{j}}
$$

6. Aşama: Karar verme sürecinin sıralaması için, alternatiflerin toplam göreli önemi denklem (13) aracılığıyla hesaplanır. Belirlenen alternatifler $Q$ değerine göre derecelendirilir. En iyi alternatif, $Q$ değerinin sahip olduğu en yüksek değer olmalıdır. WASPAS metodu; $\lambda=0$ olduğunda WPM'ye, $\lambda=1$ olduğunda ise WSM'ye dönüşür. Ayrıca, (13) numaralı denklemde görülen varyans, WSM ve WPM'ye bağlı olarak tahminlenmiş ve $\lambda$ katsayısı ile gösterilmiştir. Buna göre, çalışmada optimal $\lambda$ değeri denklem (14) aracılığıyla hesaplanmıştır.

$$
\begin{aligned}
& Q_{i}=\lambda Q_{i}^{(1)}+(1-\lambda) Q_{i}^{(2)}=\lambda \sum_{j=1}^{n} \bar{x}_{i j} \cdot w_{j}+(1-\lambda) \prod_{j=1}^{n}\left(\bar{x}_{i j}\right)^{w_{j}} \quad(\lambda=0,0.1,0.2, \ldots, 1) \\
& \lambda=\frac{\sigma^{2}\left(Q_{i}^{(2)}\right)}{\sigma^{2}\left(Q_{i}^{(1)}\right)+\sigma^{2}\left(Q_{i}^{(2)}\right)}
\end{aligned}
$$

\subsection{Analiz Sonuçları ve Bulgular}

Bu çalışmada Türkiye'de faaliyet gösteren katılım bankalarının 2010-2017 yılları arasındaki performanslarının değerlendirilmesinde kullanılan kriterler; toplam aktifler, toplam krediler ve alacaklar, toplam fon, toplam özkaynaklar, ödenmiş sermaye, şube sayısı ve çalışan sayısı olarak belirlenmiştir. Belirlenen bu kriterlerin ağrılıklarının saptanmasında Entropi yöntemi kullanılmış ve sonrasından bahsi geçen bankaların performans değerlemesi WASPAS yöntemi ile yapılmıştır. 
Türkiye'de faaliyet gösteren katılım bankalarının 2010,2011, 2012, 2013, 2014, 2015, 2016 ve 2017 yıllarına ilişkin istatistiksel verileri Tablo 1.'de gösterilmektedir.

Tablo 1. Türkiye'de Faaliyet Gösteren Katılım Bankalarına İlişkin İstatistiksel Veriler (2010-2017)

\begin{tabular}{|c|c|c|c|c|c|c|c|c|}
\hline Katılım Bankaları & Yillar & $\begin{array}{c}\text { Toplam } \\
\text { Aktifler } \\
\text { (Milyon TL) }\end{array}$ & $\begin{array}{c}\text { Toplam } \\
\text { Krediler ve } \\
\text { Alacaklar } \\
\text { (Milyon TL) }\end{array}$ & $\begin{array}{c}\text { Toplam } \\
\text { Fon } \\
\text { (Milyon TL) }\end{array}$ & \begin{tabular}{|c|} 
Toplam \\
Özkaynaklar \\
(Milyon TL)
\end{tabular} & $\begin{array}{c}\text { Ödenmiş } \\
\text { Sermaye } \\
\text { (Milyon } \\
\text { TL) }\end{array}$ & $\begin{array}{l}\text { Şube } \\
\text { Sayısı } \\
\text { (Adet) }\end{array}$ & $\begin{array}{l}\text { Çalışan } \\
\text { Sayısı } \\
\text { (Adet) }\end{array}$ \\
\hline AlbarakaTürk Katılım Bankası A.Ș. & 2010 & 8.406 .301 & 6.296 .815 & 6.881 .590 & 852.635 & 539.000 & 220 & 2.175 \\
\hline KuveytTürk Katılım Bankası A.Ș. & 2010 & 9.727 .117 & 7.055 .288 & 7.381 .473 & 1.256 .685 & 850.000 & 393 & 2.837 \\
\hline Türkiye Finans Katılım Bankası A.Ş. & 2010 & 10.691 .860 & 7.999 .620 & 8.397 .896 & 1.406 .096 & 800.000 & 287 & 3.399 \\
\hline \begin{tabular}{|l|} 
AlbarakaTürk Katılım Bankası A.Ș. \\
\end{tabular} & 2011 & 10.460 .885 & 7.286 .960 & 8.044 .747 & 1.004 .251 & 539.000 & 220 & 2.601 \\
\hline KuveytTürk Katılım Bankası A.Ș. & 2011 & 14.897 .592 & 10.391 .631 & 9.918 .327 & 1.437 .978 & 950.000 & 393 & 3.326 \\
\hline Türkiye Finans Katılım Bankası A.Ş. & 2011 & 13.528 .353 & 10.402 .875 & 9.509 .165 & 1.613 .659 & 800.000 & 287 & 3.382 \\
\hline AlbarakaTürk Katılım Bankası A.Ș. & 2012 & 12.327 .654 & 9.100 .063 & 9.225 .018 & 1.218 .333 & 900.000 & 220 & 2.758 \\
\hline KuveytTürk Katılım Bankası A.Ș. & 2012 & 18.910 .513 & 11.881 .600 & 12.755 .043 & 1.684 .037 & 1.100 .000 & 393 & 3.939 \\
\hline \begin{tabular}{|l|} 
Türkiye Finans Katılım Bankası A.Ş. \\
\end{tabular} & 2012 & 17.616 .504 & 13.067 .769 & 11.429 .536 & 2.125 .162 & 1.650 .000 & 287 & 3.595 \\
\hline AlbarakaTürk Katılım Bankası A.Ș. & 2013 & 17.216 .553 & 12.059 .901 & 12.526 .212 & 1.497 .268 & 900.000 & 220 & 3.057 \\
\hline KuveytTürk Katılım Bankası A.Ş. & 2013 & 25.893 .542 & 16.641 .338 & 17.030 .702 & 2.302 .049 & 1.700 .000 & 393 & 4.633 \\
\hline Türkiye Finans Katılım Bankası A.Ş. & 2013 & 25.126 .629 & 18.289 .610 & 15.141 .718 & 2.522 .381 & 1.775 .000 & 287 & 3.990 \\
\hline AlbarakaTürk Katılım Bankası A.Ș. & 2014 & 23.046 .424 & 16.183 .692 & 16.643 .218 & 1.790 .927 & 900.000 & 220 & 3.510 \\
\hline KuveytTürk Katılım Bankası A.Ş. & 2014 & 34.008 .175 & 21.285 .668 & 22.144 .614 & 3.022 .870 & 2.287 .005 & 393 & 5.082 \\
\hline Türkiye Finans Katılım Bankası A.Ş. & 2014 & 33.494 .790 & 24.291 .963 & 19.112 .760 & 3.153 .847 & 2.600 .000 & 287 & 4.478 \\
\hline AlbarakaTürk Katılım Bankası A.Ş. & 2015 & 29.561 .999 & 19.505 .392 & 20.346 .178 & 2.103 .914 & 900.000 & 220 & 3.736 \\
\hline KuveytTürk Katılım Bankası A.Ș. & 2015 & 42.052 .507 & 27.033 .860 & 28.122 .666 & 3.402 .490 & 2.527 .322 & 393 & 5.438 \\
\hline Türkiye Finans Katılım Bankası A.Ş. & 2015 & 38.576 .299 & 28.566 .928 & 22.177 .414 & 3.356 .757 & 2.600 .000 & 287 & 4.132 \\
\hline AlbarakaTürk Katılım Bankası A.Ș. & 2016 & 32.850 .738 & 22.722 .054 & 23.155 .134 & 2.279 .593 & 900.000 & 220 & 3.796 \\
\hline KuveytTürk Katılım Bankası A.Ş. & 2016 & 48.476 .955 & 29.956 .984 & 31.901 .763 & 3.912 .064 & 2.787 .322 & 393 & 5.588 \\
\hline Türkiye Finans Katılım Bankası A.Ş. & 2016 & 38.807 .717 & 27.016 .742 & 21.064 .781 & 3.663 .014 & 2.600 .000 & 287 & 4.024 \\
\hline AlbarakaTürk Katılım Bankası A.Ș. & 2017 & 36.229 .077 & 25.193 .463 & 25.309 .840 & 2.481 .506 & 900.000 & 229 & 3.899 \\
\hline KuveytTürk Katılım Bankası A.Ș. & 2017 & 57.123 .095 & 37.970 .541 & 39.857 .400 & 4.591 .151 & 3.097 .322 & 399 & 5.749 \\
\hline Türkiye Finans Katılım Bankası A.Ş. & 2017 & 39.080 .897 & 26.483 .453 & 22.030 .496 & 4.060 .598 & 2.600 .000 & 301 & 3.767 \\
\hline
\end{tabular}

Kaynak: Veriler Türkiye Katılım Bankaları Birliği'nin internet sayfasından derlenmiştir. (www.tkbb.org.tr)

Türkiye'de faaliyet gösteren katılım bankalarının 2010,2011, 2012, 2013, 2014, 2015 , 2016 ve 2017 yıllarına ilişkin istatistiksel verilerindeki \% değişim Tablo 2.'de gösterilmektedir. 
Tablo 2. Türkiye'de Faaliyet Gösteren Katılım Bankalarına İlişkin İstatistiksel Verilerdeki \% Değişim (2010-2017)

\begin{tabular}{|c|c|c|c|c|c|c|c|c|}
\hline $\begin{array}{c}\text { Katılım } \\
\text { Bankaları }\end{array}$ & Yillar & $\begin{array}{c}\text { Toplam } \\
\text { Aktifler } \\
(\%)\end{array}$ & $\begin{array}{c}\text { Toplam Krediler } \\
\text { ve Alacaklar } \\
(\%)\end{array}$ & $\begin{array}{c}\text { Toplam } \\
\text { Fon } \\
(\%)\end{array}$ & $\begin{array}{c}\text { Toplam } \\
\text { Özkaynaklar } \\
(\%)\end{array}$ & $\begin{array}{c}\text { Ödenmiş } \\
\text { Sermaye } \\
(\%)\end{array}$ & $\begin{array}{c}\text { Şube } \\
\text { Sayısı } \\
(\%)\end{array}$ & $\begin{array}{c}\text { Çalışan } \\
\text { Sayısı } \\
(\%)\end{array}$ \\
\hline \multirow{8}{*}{$\begin{array}{c}\text { AlbarakaTürk } \\
\text { Katılım Bankası } \\
\text { A.Ş. }\end{array}$} & 2010 & & & & & & & \\
\hline & 2011 & 24,44 & 15,72 & 16,90 & 17,78 & 0,00 & 0,00 & 19,59 \\
\hline & 2012 & 17,85 & 24,88 & 14,67 & 21,32 & 66,98 & 0,00 & 6,04 \\
\hline & 2013 & 39,66 & 32,53 & 35,79 & 22,89 & 0,00 & 0,00 & 10,84 \\
\hline & 2014 & 33,86 & 34,19 & 32,87 & 19,61 & 0,00 & 0,00 & 14,82 \\
\hline & 2015 & 28,27 & 20,52 & 22,25 & 17,48 & 0,00 & 0,00 & 6,44 \\
\hline & 2016 & 11,12 & 16,49 & 13,81 & 8,35 & 0,00 & 0,00 & 1,61 \\
\hline & 2017 & 10,28 & 10,88 & 9,31 & 8,86 & 0,00 & 4,09 & 2,71 \\
\hline \multirow{8}{*}{$\begin{array}{c}\text { KuveytTürk } \\
\text { Katılım Bankası } \\
\text { A.Ş. }\end{array}$} & 2010 & & & & & & & \\
\hline & 2011 & 53,16 & 47,29 & 34,37 & 14,43 & 11,76 & 0,00 & 17,24 \\
\hline & 2012 & 26,94 & 14,34 & 28,60 & 17,11 & 15,79 & 0,00 & 18,43 \\
\hline & 2013 & 36,93 & 40,06 & 33,52 & 36,70 & 54,55 & 0,00 & 17,62 \\
\hline & 2014 & 31,34 & 27,91 & 30,03 & 31,31 & 34,53 & 0,00 & 9,69 \\
\hline & 2015 & 23,65 & 27,00 & 27,00 & 12,56 & 10,51 & 0,00 & 7,01 \\
\hline & 2016 & 15,28 & 10,81 & 13,44 & 14,98 & 10,29 & 0,00 & 2,76 \\
\hline & 2017 & 17,84 & 26,75 & 24,94 & 17,36 & 11,12 & 1,53 & 2,88 \\
\hline \multirow{8}{*}{$\begin{array}{c}\text { Türkiye Finans } \\
\text { Katılım Bankası } \\
\text { A.Ş. }\end{array}$} & 2010 & & & & & & & \\
\hline & 2011 & 26,53 & 30,04 & 13,23 & 14,76 & 0,00 & 0,00 & $-0,50$ \\
\hline & 2012 & 30,22 & 25,62 & 20,19 & 31,70 & 106,25 & 0,00 & 6,30 \\
\hline & 2013 & 42,63 & 39,96 & 32,48 & 18,69 & 7,58 & 0,00 & 10,99 \\
\hline & 2014 & 33,30 & 32,82 & 26,23 & 25,03 & 46,48 & 0,00 & 12,23 \\
\hline & 2015 & 15,17 & 17,60 & 16,03 & 6,43 & 0,00 & 0,00 & $-7,73$ \\
\hline & 2016 & 0,60 & $-5,43$ & $-5,02$ & 9,12 & 0,00 & 0,00 & $-2,61$ \\
\hline & 2017 & 0,70 & $-1,97$ & 4,58 & 10,85 & 0,00 & 4,88 & $-6,39$ \\
\hline
\end{tabular}

Katılım bankalarına ilişkin veriler üzerinden yapılan analizlerde toplam aktifler açısından en yüksek değişimin 2011 yılında \%53.16 ile KuveytTürk Katılım Bankası A.Ş.'de gerçekleştiği görülmektedir. Buna karşın toplam aktifler açısından en düşük değiş̧imin ise 2016 yılında \%06 ile Türkiye Finans Katılım Bankası A.Ş.'de gerçekleşmiştir. Toplam krediler ve alacaklar göz önünde bulundurulduğunda yine en büyük değişimin 2011 yılında \%47,29 ile KuveytTürk Katılım Bankası A.Ş.'de gerçekleştiği görülmektedir. Buna karşın toplam krediler ve alacaklar açısından en düşük değişim 2016 yılında -\%05,43 ile Türkiye Finans Katılım Bankası A.Ş.' de gerçekleşmiştir. Toplam fon yüzdesi incelendiğinde en büyük değişimin 2013 yılında \%35.79 ile Albaraka Türk Katılım A.Ş.'de; en düşük değişimin ise \%05,02 ile Türkiye Finans Katılım Bankası A.Ş.'de gerçekleştiği göze çarpmaktadır. Toplam özkaynaklara bakıldığında en büyük değişim; 2013 yılında \%36.70 ile KuveytTürk Katılım Bankası A.Ş.'de, en düşük değişim ise 2015 yılında \%6.43 ile Türkiye Finans Katılım Bankası A.Ş.'de gerçekleşmiştir. Ödenmiş sermaye açısından en büyük değişimin 2012 yılında \%106.25 ile Türkiye Finans Katılım Bankası A.Ş.'de gerçekleştiği görülmektedir. Şube sayısı bakımından 2017 yılına kadar değişiklik göstermeyen katılım bankaları 2017 yılına gelindiğinde şube sayılarında artışa gitmişler ve şube sayısında en büyük değişimi \%4.88 ile Türkiye Finans Katılım Bankası A.Ş. göstermiştir. Katılım bankalarında yıllar itibariyle çalışan sayılarındaki değişimler göz önünde bulundurulduğunda en büyük değişimin 2011 yılında \%19.59 ile Albaraka Türk Katılım A.Ş.'de gerçekleştiği; Türkiye Finans Katılım Bankası A.Ş.'nin ise 2015 yılı itibariyle küçülmeye giderek çalışanlarını işten çıkarttığı görülmektedir. 
Türkiye'de faaliyet gösteren katılım bankalarının 2010,2011, 2012, 2013, 2014, 2015, 2016 ve 2017 yıllarına ilişkin fayda maliyet yapıları göz önünde bulundurularak seçilen her bir kriter değerinin bulunduğu yılın toplamına bölünmesiyle hazırlanan Entropi yöntemi ile normalize edilmiş karar matrisi Tablo 3.’te gösterilmektedir.

Tablo 3. Entropi Yöntemi ile Normalize Edilmiş Karar Matrisi

\begin{tabular}{|c|c|c|c|c|c|c|c|c|}
\hline Yillar & Katılım Bankaları & $\begin{array}{c}\text { Toplam } \\
\text { Aktifler }\end{array}$ & \begin{tabular}{|c|} 
Toplam \\
Krediler ve \\
Alacaklar \\
\end{tabular} & $\begin{array}{l}\text { Toplam } \\
\text { Fon }\end{array}$ & $\begin{array}{c}\text { Toplam } \\
\text { Özkaynaklar }\end{array}$ & $\begin{array}{l}\text { Ödenmiş } \\
\text { Sermaye }\end{array}$ & $\begin{array}{l}\text { Şube } \\
\text { Sayısı }\end{array}$ & $\begin{array}{c}\text { Çalışan } \\
\text { Sayısı }\end{array}$ \\
\hline \multirow{4}{*}{2010} & AlbarakaTürk Katılım Bankası A.Ş. & 291629 & & 0,303676 & $0,2+2042$ & 0,246231 & 0,244444 & 0,258590 \\
\hline & KuveytTürk Katılım Bankası A.Ş. & 337451 & 0,330432 & 0,325735 & 0,357478 & &, 436667 & \\
\hline & Türkiye Finans Katılım Bankası A.Ş. & 0,370920 & 0,374659 & 0,370589 & 0,399980 & 365464 & 0,318889 & 404114 \\
\hline & TOPLAM & 1,000000 & 1,000000 & 1,000000 & 1,000000 & 1,000000 & 1,000000 & 1,000000 \\
\hline \multirow{4}{*}{2011} & AlbarakaTü & 0,269008 & 0,259494 & 0,292832 & 0,247603 & 0,235474 & 0,244444 & 0,279407 \\
\hline & Kuvey & & & 0,36 & & & 0,436667 & \\
\hline & \begin{tabular}{|l|l|} 
Türkiy \\
\end{tabular} & 0,347890 & & 0,34 & & & & \\
\hline & TOPI & 1,000000 & 1,0 & 1,000000 & & 000 & 1,000000 & 000 \\
\hline \multirow{4}{*}{2012} & Albara & 0,252333 & 0,267260 & 0,276119 & & 0,246575 & 0,244444 & 0,267975 \\
\hline & Kuvey & 387077 & 0,34 & 0,381778 & & & & 382724 \\
\hline & Türki & & & & & & & \\
\hline & TOI & & & & & & & \\
\hline \multirow{4}{*}{2013} & & 306 & & 0,28 & & 714 & 0,244444 & 1729 \\
\hline & Kuvey & 0,379466 & 0,354140 & & & & & 0,396661 \\
\hline & Türkiye Finans Kat1 & 0,368227 & 0,3 & 51 & 04 & 714 & & 610 \\
\hline & TOP & 000 & & & & & & 000 \\
\hline \multirow{4}{*}{2014} & & 518 & & & & & & \\
\hline & Kuve & 576 & 0,3 & 0,38 & 93 & 197 & 0,436667 & 0,388829 \\
\hline & Türkiye Finans Katılım Bankası A.Ş. & 0,369906 & 0,393320 & 0,330096 & 0,395832 & 0,449282 & 0,318889 & 0,342617 \\
\hline & TOPLAM & 1,000000 & & & & 1,000000 & 1,000000 & 1,000000 \\
\hline \multirow{4}{*}{2015} & & & & & & & & \\
\hline & Kuvey & 634 & 0,35 & 0,3 & & 311 & 67 & 688 \\
\hline & Türkiye Finans Katılım Bankası A.Ş. & 0,350086 & 0,380354 & 0,313922 & 0,378731 & 0,431369 & 0,318889 & 0,310537 \\
\hline & TOPLAM & 1,000000 & 1,000000 & 1,000000 & 1,000000 & 1,000000 & 1,000000 & 1,000000 \\
\hline \multirow{4}{*}{2016} & Albar & 0,273448 & 0,285110 & & & & 0,244444 & 0,283115 \\
\hline & Kuve & & & & & & & \\
\hline & Türkiye Finans & 0,323033 & 0,338998 & 0,276725 & 0,371703 & 0,413531 & 0,318889 & 0,300119 \\
\hline & TOPLAM & 1,000000 & 1,000000 & 1,000000 & 1,000000 & 1,000000 & 1,000000 & 1,000000 \\
\hline \multirow{4}{*}{2017} & AlbarakaTür & 0,273565 & 0,281028 & 0,290258 & 0,222891 & 0,136419 & 0,246502 & 0,290645 \\
\hline & Kuvey & 0,431336 & 0,423554 & 0,457092 & & 0,469482 & 0,429494 & 0,428550 \\
\hline & Türki & & & & & 0,394099 & & 0,280805 \\
\hline & TOPLAM & 1,000000 & 1,000000 & 1,000000 & 1,000000 & 1,000000 & 1,000000 & 1,000000 \\
\hline
\end{tabular}

Faydalı bilginin miktarının ölçümlenmesi amacıyla geliştirilen Entropi yönteminde ilk önce, fayda ve maliyet yapıları göz önüne alınarak karar matrisinin normalizasyonu Tablo3.'te yapılmıştır.

Türkiye'de faaliyet gösteren katılım bankalarının 2010,2011, 2012, 2013, 2014, 2015, 2016 ve 2017 yıllarına ilişkin normalize karar matrisinin doğal logaritması ile ağırlıklandırılması (Rijxlnij) Tablo 4.’te gösterilmektedir. 
Tablo 4. Normalize Karar Matrisinin Doğal Logaritması İle Ağırlıklandırılması (Rijxlnij)

\begin{tabular}{|c|c|c|c|c|c|c|c|c|}
\hline Yillar & Katılım Bankaları & $\begin{array}{c}\text { Toplam } \\
\text { Aktifler }\end{array}$ & \begin{tabular}{|c|} 
Toplam \\
Krediler ve \\
Alacaklar
\end{tabular} & $\begin{array}{l}\text { Toplam } \\
\text { Fon }\end{array}$ & $\begin{array}{c}\text { Toplam } \\
\text { Özkaynaklar }\end{array}$ & $\begin{array}{l}\text { Ödenmiş } \\
\text { Sermaye }\end{array}$ & $\begin{array}{l}\text { Şube } \\
\text { Sayısı }\end{array}$ & $\begin{array}{c}\text { Çalışan } \\
\text { Sayısı }\end{array}$ \\
\hline \multirow{4}{*}{2010} & AlbarakaTürk Katılım Bankası A.Ş. &, 359367 & $-0,360110$ & $-0,361919$ & $-0,343580$ & $-0,345089$ & $-0,344365$ & $-0,349746$ \\
\hline & KuveytTürk Katılım Bankası A.S. & & & & & & & \\
\hline & Türkiye Finans Katılım Bankası A.Ş. & $-0,367867$ & $-0,367817$ & $-0,367869$ & $-0,366518$ & $-0,367871$ & $-0,364462$ & $-0,366151$ \\
\hline & TOPLAM & $-1,093818$ & $-1,093833$ & $-1,095156$ & & $-1,080283$ & $-1,070643$ & $-1,082468$ \\
\hline \multirow{4}{*}{2011} & AlbarakaTü & $-0,353211$ & $-0,350063$ & $-0,359643$ & $-0,345636$ & & $-0,344365$ & $-0,356268$ \\
\hline & KuveytTür & $-0,367569$ & $-0,367873$ & $-0,367815$ & & & & \\
\hline & Türki & & $-0,367870$ & & & & & \\
\hline & TOP & $-1,0$ & & $-1,0$ & & & & \\
\hline \multirow{4}{*}{2012} & & & & $-0,3$ & & & & \\
\hline & Kuve & $-0,367387$ & $-0,367384$ & $-0,367620$ & & & & \\
\hline & Türki & $-0,367$ & $-0,367540$ & $-0,36$ & & & & \\
\hline & TO & & & & & & & \\
\hline \multirow{4}{*}{2013} & & & & $-0,3$ & & & & \\
\hline & Kuve & $-0,3$ & $-0,3$ & $-0,3$ & & & & \\
\hline & Türki & $-0,367879$ & $-0,36$ & $-0,36$ & & & & \\
\hline & TOPL & & $-1,083944$ & & & & & \\
\hline \multirow{4}{*}{2014} & & & & & & & & \\
\hline & & 99 & $-0,3$ & $-0,3$ & & & & \\
\hline & Türki & $-0,36$ & $-0,36$ & $-0,36$ & & & $-0,3$ & $-0,3$ \\
\hline & TOPI & $-1,083952$ & $-1,085087$ & $-1,09$ & & & & \\
\hline \multirow{4}{*}{2015} & $\mathrm{Alb}$ & & & & & & & \\
\hline & Kuve & & & & & & & \\
\hline & Türk & $-0,3$ & $-0,36$ & $-0,36$ & -0, & 91 & $-0,3$ & $-0,3$ \\
\hline & TOPI & $-1,088050$ & $-1,085600$ & $-1,088887$ & $-1,07$ & 1089 & $-1,070643$ & $-1,085495$ \\
\hline \multirow{4}{*}{2016} & AlbarakaTü & $-0,354565$ & $-0,357779$ & $-0,362017$ & $-0,338642$ & $-0,278259$ & $-0,344365$ & $-0,357263$ \\
\hline & Kuve & & & & & & & \\
\hline & Türki & & $-0,3$ & & & & $-0,364462$ & \\
\hline & TOPLAM & $-1,085798$ & $-1,092287$ & $-1,082004$ & $-1,073260$ & $-1,004041$ & $-1,070643$ & $-1,083246$ \\
\hline \multirow{4}{*}{2017} & AlbarakaTürk Katı & $-0,354599$ & $-0,356709$ & $-0,359045$ & $-0,334576$ & $-0,271750$ & $-0,345198$ & $-0,359136$ \\
\hline & KuveytTürk Katılım Bankası A.Ş. & $-0,362697$ & $-0,363864$ & $-0,357844$ & $-0,365290$ & $-0,354987$ & $-0,362986$ & \begin{tabular}{|l|}
$-0,363131$ \\
\end{tabular} \\
\hline & Türkiye & $-0,360152$ & $-0,360222$ & $-0,347583$ & $-0,367866$ & $-0,366966$ & $-0,365152$ & $-0,356649$ \\
\hline & TOPLAM & $-1,077448$ & $-1,080796$ & $-1,064472$ & $-1,067732$ & $-0,993704$ & $-1,073336$ & $-1,078916$ \\
\hline
\end{tabular}

Tablo 4.'te Eji değerinin ve $\mathrm{k}$ değerinin hesaplanması için Tablo 3'teki her bir kriter değerinin (Rij), doğal logaritması alınmış (lnij) ve alınan logaritma değeri ile kendi değeri çarpılmıştır.

Tablo 4'te bulunan değerlerin toplamları alınarak Ej değeri (4) numaralı denklem kullanılarak hesaplanmıştır. Daha sonra, (5) numaralı denklem yardımıyla her bir Eij değerinden 1 çıkarılarak dij belirsizliği elde edilmiştir. Son aşamada ise, j kriterinin önem derecesinin belirlenmesi için wj ağırlık değerleri hesaplanmıştır. Son üç aşamada elde edilen 2010,2011, 2012, 2013, 2014, 2015, 2016 ve 2017 yıllarına ilişkin Eij, dj ve wj değerleri Tablo 5.'te gösterilmektedir. 
Tablo 5. Eij, dj ve wj Değerleri

\begin{tabular}{|c|c|c|c|c|c|c|c|c|}
\hline Yillar & Değerler & $\begin{array}{l}\text { Toplam } \\
\text { Aktifler }\end{array}$ & $\begin{array}{c}\text { Toplam } \\
\text { Krediler ve } \\
\text { Alacaklar }\end{array}$ & $\begin{array}{l}\text { Toplam } \\
\text { Fon }\end{array}$ & $\begin{array}{c}\text { Toplam } \\
\text { Özkaynaklar }\end{array}$ & $\begin{array}{l}\text { Ödenmiş } \\
\text { Sermaye }\end{array}$ & $\begin{array}{l}\text { Şube } \\
\text { Sayısı }\end{array}$ & $\begin{array}{c}\text { Çalışan } \\
\text { Sayısı }\end{array}$ \\
\hline \multirow{3}{*}{2010} & $E i j$ & 0,995636 & 0,995649 & 0,996854 & 0,981082 & 0,983316 & 0,974541 & 0,985305 \\
\hline & $d j$ & 0,004364 & 0,004351 & 0,003146 & 0,018918 & 0,016684 & 0,025459 & 0,014695 \\
\hline & $w j$ & 0,049805 & 0,049656 & 0,035905 & 0,215918 & 0,190421 & 0,290575 & 0,167721 \\
\hline \multirow{3}{*}{2011} & $E i j$ & 0,990437 & 0,988344 & 0,996423 & 0,983023 & 0,976617 & 0,974541 & 0,993839 \\
\hline & $d j$ & 0,009563 & 0,011656 & 0,003577 & 0,016977 & 0,023383 & 0,025459 & 0,006161 \\
\hline & $w j$ & 0,098814 & 0,120448 & 0,036961 & 0,175429 & 0,241619 & 0,263070 & 0,063658 \\
\hline \multirow{3}{*}{2012} & $E i j$ & 0,985478 & 0,989961 & 0,992087 & 0,977448 & 0,969955 & 0,974541 & 0,990224 \\
\hline & $d j$ & 0,014522 & 0,010039 & 0,007913 & 0,022552 & 0,030045 & 0,025459 & 0,009776 \\
\hline & $w j$ & 0,120712 & 0,083449 & 0,065776 & 0,187452 & 0,249734 & 0,211616 & 0,081261 \\
\hline \multirow{3}{*}{2013} & $E i j$ & 0,985818 & 0,986649 & 0,992923 & 0,979052 & 0,963574 & 0,974541 & 0,987185 \\
\hline & $d j$ & 0,014182 & 0,013351 & 0,007077 & 0,020948 & 0,036426 & 0,025459 & 0,012815 \\
\hline & $w j$ & 0,108875 & 0,102500 & 0,054331 & 0,160818 & 0,279644 & 0,195450 & 0,098381 \\
\hline \multirow{3}{*}{2014} & $E i j$ & 0,986655 & 0,987689 & 0,993824 & 0,974007 & 0,924605 & 0,974541 & 0,989752 \\
\hline & $d j$ & 0,013345 & 0,012311 & 0,006176 & 0,025993 & 0,075395 & 0,025459 & 0,010248 \\
\hline & $w j$ & 0,078998 & 0,072880 & 0,036557 & 0,153872 & 0,446320 & 0,150710 & 0,060663 \\
\hline \multirow{3}{*}{2015} & $E i j$ & \begin{tabular}{|l|}
0,990386 \\
\end{tabular} & 0,988156 & 0,991148 & 0,979991 & 0,920333 & 0,974541 & 0,988060 \\
\hline & $d j$ & 0,009614 & 0,011844 & 0,008852 & 0,020009 & 0,079667 & 0,025459 & \begin{tabular}{|l|}
0,011940 \\
\end{tabular} \\
\hline & $w j$ & 0,057437 & 0,070761 & 0,052885 & 0,119537 & 0,475949 & 0,152096 & 0,071334 \\
\hline \multirow{3}{*}{2016} & $E i j$ & 0,988336 & 0,994242 & 0,984882 & 0,976923 & 0,913917 & 0,974541 & 0,986013 \\
\hline & $d j$ & 0,011664 & 0,005758 & 0,015118 & 0,023077 & 0,086083 & 0,025459 & 0,013987 \\
\hline & $w j$ & 0,064389 & 0,031786 & 0,083456 & 0,127394 & 0,475215 & 0,140544 & 0,077216 \\
\hline \multirow{3}{*}{2017} & $E i j$ & 0,980735 & 0,9837825 & 0,968924 & 0,971891306 & 0,904508 & 0,976992 & 0,982072 \\
\hline & $d j$ & 0,019265 & 0,0162175 & 0,031076 & 0,028108694 & 0,095492 & 0,023008 & 0,017928 \\
\hline & $w j$ & 0,083362 & 0,070177 & 0,134473 & 0,121632902 & 0,413216 & 0,09956 & 0,07758 \\
\hline
\end{tabular}

Tablo 6. itibariyle WASPAS yöntemi ile katılım bankalarının performanslarının değerlendirilmesi yapılacaktır. WASPAS yönteminin birinci aşaması, Entropi yönteminde olduğu gibi karar matrisinin oluşturulması ve bu matrisin normalize edilmesini içermektedir. WASPAS yönteminde oluşturulan karar matrisi üzerinde her bir fayda kriteri için denklem (8), buna karşın her bir maliyet kriteri için denklem (9) kullanılarak normalize işlemi yapılmıştır. Toplam aktifler, toplam krediler ve alacaklar, toplam mevduat, toplam özkaynaklar ve ödenmiş sermaye tutarlarının bankaya fayda sağladığı, buna karşın şube sayısı ve çalışan sayısı adetlerinin maliyet unsuru olduğu kabul edilmiştir. Türkiye'de faaliyet gösteren katılım bankalarının 2010,2011, 2012, 2013, 2014, 2015, 2016 ve 2017 yıllarına ilişkin normalize edilmiş karar matrisi Tablo 6.'da gösterilmektedir. 
Tablo 6. Normalize Edilmiş Karar Matrisi

\begin{tabular}{|c|c|c|c|c|c|c|c|c|}
\hline Yillar & Katılım Bankaları & $\begin{array}{l}\text { Toplam } \\
\text { Aktifler }\end{array}$ & \begin{tabular}{c|} 
Toplam \\
Krediler ve \\
Alacaklar
\end{tabular} & $\begin{array}{l}\text { Toplam } \\
\text { Fon }\end{array}$ & $\begin{array}{c}\text { Toplam } \\
\text { Özkaynaklar }\end{array}$ & $\begin{array}{l}\text { Ödenmiş } \\
\text { Sermaye }\end{array}$ & $\begin{array}{l}\text { Şube } \\
\text { Sayısı }\end{array}$ & $\begin{array}{c}\text { Çalışan } \\
\text { Sayısı }\end{array}$ \\
\hline \multirow{3}{*}{2010} & AlbarakaTürk Katılım Bankası A.Ș. & 786234 & 0,787139 & 0,819442 & 0,606385 & 0,634118 & 1,000000 & 1,000000 \\
\hline & KuveytTürk Katılım Bankası A.Ș. & & 0,881953 & & & & 0,559796 & 0,766655 \\
\hline & Türkiye Finans Katılım Bankası A.Ș. & 1,000000 & 1,000000 & 1,000000 & 1,000000 & 0,941176 & 0,766551 & 0,639894 \\
\hline \multirow{3}{*}{2011} & AlbarakaTürk Katılım Bankası A.Ş. & 702186 & 0,700476 & 0,811099 & 0,62 & 0,567368 & 1,000000 & 1,000000 \\
\hline & KuveytTürk Katılım Bankası A.Ș. & 1,000000 & 0,998919 & 1,000000 & 0,891129 & & 0,559796 & 0,782020 \\
\hline & Türkiye Finans Katılım Bankası A.Ș. & & 1,000000 & & & & & \\
\hline \multirow{3}{*}{2012} & AlbarakaTürk Katılım Ba & & 0,696375 & 0,723245 & & 0,545455 & 1,000000 & \\
\hline & KuveytTürk Katılım Bankası A.Ş. & 1,000000 & 0,909229 & 1,000000 & 0,792428 & 0,666667 & 0,559796 & 0,700178 \\
\hline & Türkiye Finans $\mathbf{F}$ & 0,931572 & 1,000000 & 0,896080 & 1,000000 & 1,000000 & 0,766551 & 0,767177 \\
\hline \multirow{3}{*}{2013} & Albar & & & & & & 0 & \\
\hline & KuveytTürk Ka & 1,000000 & 0,909879 & 1,000000 & 0,912649 & 0,957746 & 0,559796 & 0,659832 \\
\hline & Türkiye Finans Katılım Bankası A.Ş. & 0,970382 & 1,000000 & 0,889084 & 1,000000 & 1,000000 & 0,766551 & 0,766165 \\
\hline \multirow{3}{*}{2014} & AlbarakaTürk Katılım Bankası & 73 & 0,6 & 0,751570 & 0,567855 & 0,346154 & 000000 & 000 \\
\hline & Kuveyt Türk Katılım & & 0,87 & 1,00 & & & 0,559796 & 0,690673 \\
\hline & Türkiye Finans Katılım Bankası A.Ș. & 904 & 1,000000 & 0,863088 & 1,000000 & 1,000000 & 0,766551 & 0,783832 \\
\hline \multirow{3}{*}{2015} & AlbarakaTürk Katılım B & 02978 & 0,682796 & 0,72 & 0,618345 & 346154 & 1,000000 & 1,0 \\
\hline & KuveytTürk Katılım Bankası A.Ș. & 1,000000 & 0,94 & 1,000000 & & & 0,559796 & 0,687017 \\
\hline & Türkiye Finans Katılım Bankası A.Ș. & 0,917336 & 1,000000 & 0,788596 & 0,986559 & 1,000000 & 0,766551 & 0,904163 \\
\hline \multirow{3}{*}{2016} & AlbarakaTürk Katılım Bankası A.Ş. & 0,677657 & 0,758489 & 0,725826 & 0,582709 & 0,322891 & 1,000000 & 1,000000 \\
\hline & KuveytTürk Katılım Bankası A.Ş. & 1,000000 & 1,000000 & 1,000000 & 1,000000 & 1,000000 & 0,559796 & 0,679313 \\
\hline & Türkiye Finans Katılım Bankası A.Ş. & 0,800539 & 0,901851 & 0,660301 & 0,936338 & 0,932795 & 0,766551 & 0,943340 \\
\hline \multirow{3}{*}{2017} & AlbarakaTürk Katılım Bankası A.Ș. & 0,634228 & 0,663500 & 0,635010 & 0,540 & 0,290574 & 1,000000 & 0,966145 \\
\hline & KuveytTürk Katılım Bankası A.Ș. & 1,000000 & 1,000000 & 1,000000 & 1,000000 & 1,000000 & 0,573935 & 0,655244 \\
\hline & Türkiye Finans Katılım Bankası A.Ș. & 0,684152 & 0,697474 & 0,552733 & 0,884440 & 0,839435 & 0,760797 & 1,000000 \\
\hline
\end{tabular}

Sonraki aşamada (10) numaralı denklem yardımıyla Ağırlıklı Toplam Modeline (WSM) dayalı görece öneminin hesaplanması amacıyla, normalize edilmiş karar matrisi üzerinden her bir i alternatif değeri Entropi yönteminin son aşamasında elde edilen ilgili kriter ağırlık değeri ile çarpılmış ve her bir kamu sermayeli banka için toplam alınarak Tablo 7.'de yer alan Qi(1) değerleri bulunmuştur. Türkiye'de faaliyet gösteren katılım bankalarının 2010,2011, 2012, 2013, 2014, 2015, 2016 ve 2017 yıllarına ilişkin ağırlıklı toplam modeline (WSM) dayalı toplam görece önem değerleri Tablo 7.’de gösterilmektedir. 
Tablo 7. Ağırlıklı Toplam Modeline (WSM) Dayalı Toplam Görece Önem Değerleri

\begin{tabular}{|c|c|c|c|c|c|c|c|c|c|}
\hline Yillar & Katılım Bankaları & $\begin{array}{l}\text { Toplam } \\
\text { Aktifler }\end{array}$ & $\begin{array}{c}\text { Toplam } \\
\text { Krediler ve } \\
\text { Alacaklar }\end{array}$ & $\begin{array}{c}\text { Toplam } \\
\text { Fon }\end{array}$ & $\begin{array}{c}\text { Toplam } \\
\text { Özkaynaklar }\end{array}$ & $\begin{array}{l}\text { Ödenmiş } \\
\text { Sermaye }\end{array}$ & $\begin{array}{l}\text { Şube } \\
\text { Sayısı }\end{array}$ & $\begin{array}{l}\text { Çalışan } \\
\text { Sayısı }\end{array}$ & $Q_{i}^{(1)}$ \\
\hline \multirow{3}{*}{2010} & AlbarakaTürk Katılım Bankası A.Ş. & 0,039158 & 0,039086 & 0,029422 & 0,130929 & 0,120749 & 0,290575 & 0,167721 & 0,817641 \\
\hline & KuveytTürk Katılım Bankası A.Ş. & 0,045311 & 0,043794 & 0,031559 & 0,192974 & 0,190421 & 0,162663 & 0,128584 & 0,795306 \\
\hline & Türkiye Finans Katılım Bankası A.Ş. & 0,049805 & 0,049656 & 0,035905 & 0,215918 & 0,179220 & 0,222740 & 0,107324 & 0,860567 \\
\hline \multirow{3}{*}{2011} & AlbarakaTürk Katılım Bankası A.Ş. & 0,069386 & 0,084371 & 0,029979 & 0,109177 & 0,137087 & 0,263070 & 0,063658 & 0,756729 \\
\hline & KuveytTürk Katılım Bankası A.Ş. & 0,098814 & 0,120318 & 0,036961 & 0,156330 & 0,241619 & 0,147266 & 0,049782 & 0,851090 \\
\hline & Türkiye Finans Katılım Bankası A.Ş. & 0,089732 & 0,120448 & 0,035437 & 0,175429 & 0,203469 & 0,201657 & 0,048957 & 0,875129 \\
\hline \multirow{3}{*}{2012} & AlbarakaTürk Katılım Bankası A.Ş. & 0,078691 & 0,058112 & 0,047572 & 0,107464 & 0,136218 & 0,211616 & 0,081261 & 0,720935 \\
\hline & KuveytTürk Katılım Bankası A.Ş. & 0,120712 & 0,075874 & 0,065776 & 0,148542 & 0,166489 & 0,118462 & 0,056897 & 0,752753 \\
\hline & Türkiye Finans Katılım Bankası A.Ş. & 0,112452 & 0,083449 & 0,058941 & 0,187452 & 0,249734 & 0,162215 & 0,062341 & 0,916583 \\
\hline \multirow{3}{*}{2013} & AlbarakaTürk Katılım Bankası A.Ş. & 0,072391 & 0,067587 & 0,039961 & 0,095461 & 0,141791 & 0,195450 & 0,098381 & 0,711022 \\
\hline & KuveytTürk Katılım Bankası A.Ş. & 0,108875 & & 0,054331 & & 0,267828 & 0,109412 & 0,064915 & 0,845395 \\
\hline & Türkiye Finans Katılım Bankası A.Ş. & 0,105651 & 0,102500 & 0,048305 & 0,160818 & 0,279644 & 0,149823 & 0,075376 & 0,922116 \\
\hline \multirow{3}{*}{2014} & AlbarakaTürk Katılım Bankası A.Ş. & 0,053535 & 0,048554 & 0,027476 & 0,087377 & 0,154495 & 0,150710 & 0,060663 & 0,582809 \\
\hline & KuveytTürk Katılım Bankası A.Ş. & 0,078998 & 0,063861 & 0,036557 & 0,147482 & 0,392591 & 0,084367 & 0,041898 & 0,845754 \\
\hline & Türkiye Finans Katılım Bankası A.Ş. & 0,077805 & 0,072880 & 0,031552 & 0,153872 & 0,446320 & 0,115527 & 0,047550 & 0,945506 \\
\hline \multirow{3}{*}{2015} & AlbarakaTürk Katılım Bankası A.Ş. & 0,040377 & 16 & 0,038261 & 915 & 0,164752 & 0,152096 & 0,071334 & 0,589051 \\
\hline & KuveytTürk Katılım Bankası A.Ş. & 0,057437 & 0,066964 & 0,052885 & 0,119537 & 0,462645 & 0,085143 & 0,049008 & 0,893619 \\
\hline & Türkiye Finans Katılım Bankası A.Ş. & 0,052689 & 0,070761 & 0,041705 & 0,117931 & 0,475949 & 0,116589 & 0,064497 & 0,940122 \\
\hline \multirow{3}{*}{2016} & AlbarakaTürk Katılım Bankası A.Ş. & 0,043634 & 0,024110 & 0,060575 & 0,074234 & 0,153442 & 0,140544 & 0,077216 & 0,573753 \\
\hline & KuveytTürk Katılım Bankası A.Ş. & 0,064389 & 0,031786 & 0,083456 & 0,127394 & 0,475215 & 0,078676 & 0,052454 & 0,913370 \\
\hline & Türkiye Finans Katılım Bankası A.Ş. & 0,051546 & 0,028666 & 0,055106 & 0,119284 & 0,443278 & 0,107734 & 0,072841 & 0,878455 \\
\hline \multirow{3}{*}{2017} & AlbarakaTürk Katılım Bankası A.Ş. & 0,052871 & 0,046562 & 0,085392 & 0,065742 & 0,120070 & 0,099560 & 0,074953 & 0,545149 \\
\hline & KuveytTürk Katılım Bankası A.Ş. & 0,083362 & 0,070177 & 0,134473 & 0,121633 & 0,413216 & 0,057141 & 0,050834 & 0,930835 \\
\hline & Türkiye Finans Katılım Bankası A.Ş. & 0,057032 & 0,048947 & 0,074328 & 0,107577 & 0,346868 & 0,075745 & 0,077580 & 0,788076 \\
\hline
\end{tabular}

Bu aşamada ise (11) numaralı denklem yardımıyla, Ağırlıklı Çarpım Modeline (WPM) dayalı i. alternatifin toplam görece öneminin hesaplanması amacıyla, yine normalize edilmiş karar matrisi üzerinden her bir i.alternatif değeri için ilgili kriter ağırlığının kuvveti alınmış ve bulunan değerler her bir alternatif için sırasıyla çarpılarak Tablo 8.' de yer alan Qi(2)değerleri hesaplanmıştır. Türkiye'de faaliyet gösteren katılım bankalarının 2010,2011, 2012, 2013, 2014, 2015, 2016 ve 2017 yıllarına ilişkin ağırlıklı çarpım modeline (WPM) dayalı toplam görece önem değerleri Tablo 8.'de gösterilmektedir. 
Tablo 8. Ağırlıklı Çarpım Modeline (WPM) Dayalı Toplam Görece Önem Değerleri

\begin{tabular}{|c|c|c|c|c|c|c|c|c|c|}
\hline Yillar & Katılım Bankaları & $\begin{array}{l}\text { Toplam } \\
\text { Aktifler }\end{array}$ & \begin{tabular}{|c|} 
Toplam \\
Krediler ve \\
Alacaklar
\end{tabular} & $\begin{array}{l}\text { Toplam } \\
\text { Fon }\end{array}$ & $\begin{array}{c}\text { Toplam } \\
\text { Özkaynaklar }\end{array}$ & $\begin{array}{l}\text { Ödenmiş } \\
\text { Sermaye }\end{array}$ & $\begin{array}{l}\text { Şube } \\
\text { Sayısı }\end{array}$ & $\begin{array}{l}\text { Çalışan } \\
\text { Sayısı }\end{array}$ & $Q_{i}^{(2)}$ \\
\hline \multirow{3}{*}{2010} & AlbarakaTürk Katılım Bankası A.Ș. & 0,988093 & 0,988185 & 0,992876 & 0,897618 & 0,916915 & 1,000000 & 1,000000 & 0,797906 \\
\hline & KuveytTürk Katılım Bankası A.Ş. & 0,995301 & 0,993782 & 0,995379 & 0,976036 & 1,000000 & 0,844858 & 0,956412 & 0,776477 \\
\hline & Türkiye Finans Katılım Bankası A.Ș. & 1,000000 & 1,000000 & 1,000000 & 1,000000 & 0,988522 & 0,925658 & 0,927855 & 0,849018 \\
\hline \multirow{3}{*}{2011} & AlbarakaTürk Katılım Bankası A.Ş. & 0,965667 & 0,958027 & 0,992291 & 0,920168 & 0,872025 & 1,000000 & 1,000000 & 0,736615 \\
\hline & KuveytTürk Katılım Bankası A.Ş. & 1,000000 & 0,999870 & 1,000000 & 0,979982 & 1,000000 & 0,858448 & 0,984470 & 0,828091 \\
\hline & Türkiye Finans Katılım Bankası A.Ş. & 0,990518 & 1,000000 & 0,998444 & 1,000000 & 0,959328 & 0,932451 & 0,983424 & 0,870002 \\
\hline \multirow{3}{*}{2012} & AlbarakaTürk Katılım Bankası A.Ş. & 0,949662 & 0,970254 & 0,978913 & 0,900962 & 0,859527 & 1,000000 & 1,000000 & 0,698498 \\
\hline & KuveytTürk Katılım Bankası A.Ş. & 1,000000 & 0,992091 & 1,000000 & 0,957326 & 0,903700 & 0,884462 & 0,971452 & 0,737455 \\
\hline & Türkiye Finans Katılım Bankası A.Ş. & 0,991480 & 1,000000 & 0,992809 & 1,000000 & 1,000000 & 0,945294 & 0,978693 & 0,910674 \\
\hline \multirow{3}{*}{2013} & AlbarakaTürk Katılım Bankası A.Ş. & 0,956538 & 0,958213 & 0,983448 & 0,919545 & 0,827023 & 1,000000 & 1,000000 & 0,685498 \\
\hline & KuveytTürk Katılım Bankası A.Ş. & 1,000000 & 0,990366 & 1,000000 & 0,985408 & 0,988000 & 0,892796 & 0,959921 & 0,826336 \\
\hline & Türkiye Finans Katılım Bankası A.Ş. & 0,996732 & 1,000000 & 0,993633 & 1,000000 & 1,000000 & 0,949366 & 0,974136 & 0,915920 \\
\hline \multirow{3}{*}{2014} & AlbarakaTürk Katılım Bankası A.Ș. & 0,969730 & 0,970834 & 0,989614 & 0,916609 & 0,622826 & 1,000000 & 1,000000 & 0,531878 \\
\hline & KuveytTürk Katılım Bankası A.Ş. & 1,000000 & 0,990418 & 1,000000 & 0,993495 & 0,944359 & 0,916275 & 0,977799 & 0,832524 \\
\hline & Türkiye Finans Katılım Bankası A.Ş. & 0,998799 & 1,000000 & 0,994632 & 1,000000 & 1,000000 & 0,960725 & 0,985333 & 0,940422 \\
\hline \multirow{3}{*}{2015} & AlbarakaTürk Katılım Bankası A.Ş. & 0,979961 & 0,973362 & 0,983028 & 0,944157 & 0,603553 & 1,000000 & 1,000000 & 0,534329 \\
\hline & KuveytTürk Katılım Bankası A.Ş. & 1,000000 & 0,996104 & 1,000000 & 1,000000 & 0,986597 & 0,915538 & 0,973577 & 0,875974 \\
\hline & Türkiye Finans Katılım Bankası A.Ş. & 0,995057 & 1,000000 & 0,987518 & 0,998384 & 1,000000 & 0,960371 & 0,992839 & 0,935424 \\
\hline \multirow{3}{*}{2016} & AlbarakaTürk Katılım Bankası A.Ş. & 0,975257 & 0,991252 & 0,973611 & 0,933512 & 0,584381 & 1,000000 & 1,000000 & 0,513457 \\
\hline & KuveytTürk Katılım Bankası A.Ş. & 1,000000 & 1,000000 & 1,000000 & 1,000000 & 1,000000 & 0,921695 & 0,970584 & 0,894583 \\
\hline & Türkiye Finans Katılım Bankası A.Ş. & 0,985778 & 0,996722 & 0,965954 & 0,991655 & 0,967480 & 0,963325 & 0,995506 & 0,873230 \\
\hline \multirow{3}{*}{2017} & AlbarakaTürk Katılım Bankası A.Ş. & 0,962753 & 0,971622 & 0,940761 & 0,927895 & 0,600080 & 1,000000 & 0,997332 & 0,488696 \\
\hline & KuveytTürk Katılım Bankası A.Ş. & 1,000000 & 1,000000 & 1,000000 & 1,000000 & 1,000000 & 0,946221 & 0,967735 & 0,915691 \\
\hline & Türkiye Finans Katılım Bankası A.Ş. & 0,968853 & 0,975033 & 0,923369 & 0,985174 & 0,930230 & 0,973149 & 1,000000 & 0,777920 \\
\hline
\end{tabular}

WSM ve WPM kapsamında $Q_{i}^{(1)}$ ve $Q_{i}^{(2)}$ değerleri hesaplandıktan sonra (12) numaralı denklem yardımıyla Ağırlıklandırılmış Ortak Genel Kriter Değerleri $Q_{i}$ hesaplanmış, ardından sıralama yapılmıştır. Elde edilen $Q_{i}$ değerleri ve elde edilen sıralama değerleri Tablo 9'da yer almaktadır. Türkiye'de faaliyet gösteren katılım bankalarının 2010,2011, 2012, 2013, 2014, 2015, 2016 ve 2017 yıllarına ilişkin ağırlıklandırılmış ortak genel kriter değerleri ve sıralaması Tablo 9.'da gösterilmektedir. 
Tablo 9. Ağırlıklandırılmış Ortak Genel Kriter Değerleri ve Sıralaması

\begin{tabular}{|c|c|c|c|c|}
\hline Yillar & Katılım Bankaları & $Q_{i}$ & Siralama & En İyi Performans \\
\hline \multirow{3}{*}{2010} & AlbarakaTürk Katılım Bankası A.Ş. & 0,807773 & 2 & \multirow{3}{*}{$\begin{array}{c}\text { Türkiye Finans } \\
\text { Katılım Bankası A.Ş. }\end{array}$} \\
\hline & KuveytTürk Katılım Bankası A.Ş. & 0,785892 & 3 & \\
\hline & Türkiye Finans Katılım Bankası A.Ş. & 0,854793 & 1 & \\
\hline \multirow{3}{*}{2011} & AlbarakaTürk Katılım Bankası A.Ş. & 0,746672 & 3 & \multirow{3}{*}{$\begin{array}{c}\text { Türkiye Finans } \\
\text { Katılım Bankası A.Ş. }\end{array}$} \\
\hline & KuveytTürk Katılım Bankası A.Ş. & 0,839591 & 2 & \\
\hline & Türkiye Finans Katılım Bankası A.Ş. & 0,872566 & 1 & \\
\hline \multirow{3}{*}{2012} & AlbarakaTürk Katılım Bankası A.Ş. & 0,709717 & 3 & \multirow{3}{*}{$\begin{array}{c}\text { Türkiye Finans } \\
\text { Katılım Bankası A.Ş. }\end{array}$} \\
\hline & KuveytTürk Katılım Bankası A.Ş. & 0,745104 & 2 & \\
\hline & Türkiye Finans Katılım Bankası A.Ş. & 0,913629 & 1 & \\
\hline \multirow{3}{*}{2013} & AlbarakaTürk Katılım Bankası A.Ş. & 0,698260 & 3 & \multirow{3}{*}{$\begin{array}{c}\text { Türkiye Finans } \\
\text { Katılım Bankası A.Ş. }\end{array}$} \\
\hline & KuveytTürk Katılım Bankası A.Ş. & 0,835866 & 2 & \\
\hline & Türkiye Finans Katılım Bankası A.Ş. & 0,919018 & 1 & \\
\hline \multirow{3}{*}{2014} & AlbarakaTürk Katılım Bankası A.Ş. & 0,557344 & 3 & \multirow{3}{*}{$\begin{array}{c}\text { Türkiye Finans } \\
\text { Katılım Bankası A.Ş. }\end{array}$} \\
\hline & KuveytTürk Katılım Bankası A.Ş. & 0,839139 & 2 & \\
\hline & Türkiye Finans Katılım Bankası A.Ş. & 0,942964 & 1 & \\
\hline \multirow{3}{*}{2015} & AlbarakaTürk Katılım Bankası A.Ş. & 0,561690 & 3 & \multirow{3}{*}{$\begin{array}{c}\text { Türkiye Finans } \\
\text { Katılım Bankası A.Ş. }\end{array}$} \\
\hline & KuveytTürk Katılım Bankası A.Ş. & 0,884796 & 2 & \\
\hline & Türkiye Finans Katılım Bankası A.Ş. & 0,937773 & 1 & \\
\hline \multirow{3}{*}{2016} & AlbarakaTürk Katılım Bankası A.Ş. & 0,543605 & 3 & \multirow{3}{*}{$\begin{array}{c}\text { KuveytTürk Katılım } \\
\text { Bankası A.Ş. }\end{array}$} \\
\hline & KuveytTürk Katılım Bankası A.Ş. & 0,903976 & 1 & \\
\hline & Türkiye Finans Katılım Bankası A.Ş. & 0,875843 & 2 & \\
\hline \multirow{3}{*}{2017} & AlbarakaTürk Katılım Bankası A.Ş. & 0,5169228 & 3 & \multirow{3}{*}{$\begin{array}{c}\text { KuveytTürk Katılım } \\
\text { Bankası A.Ş. }\end{array}$} \\
\hline & KuveytTürk Katılım Bankası A.Ş. & 0,9232631 & 1 & \\
\hline & Türkiye Finans Katılım Bankası A.Ş. & 0,782998 & 2 & \\
\hline
\end{tabular}

Tablo 9 incelendiğinde; 2010, 2011, 2012, 2013, 2014, ve 2015 yılları için en iyi performansı gösteren katılım bankasının Türkiye Finans Katılım Bankası A.Ş. iken; 2016 ve 2017 yılları için en iyi performans katılım bankasının KuvetTürk Katılım Bankası A.Ş. olduğu görülmektedir.

WASPAS yönteminde, karar verme sürecinin sıralama doğruluğunu ve etkinliğini artması amaciyla lambda $(\lambda)$ etkisine bakılmaktadır. Alternatiflerin toplam göreli önemini belirlemek için daha genel bir adım olan sıralama üzerinde $\lambda$ etkisi (13) numaralı denklem kullanılarak hesaplanmış ve Tablo 10.'da gösterilmektedir. 
Tablo 10. WASPAS Yönteminin Performans Siralaması Üzerinde $\lambda$ Etkisi ve Optimal $\lambda$ Değeri

\begin{tabular}{|c|c|c|c|c|c|c|c|c|c|c|c|c|c|c|}
\hline \multirow{2}{*}{ Yillar } & \multirow{2}{*}{ Katılım Bankaları } & \multicolumn{11}{|c|}{ Alternatif $\lambda$ Değerleri } & \multirow[b]{2}{*}{ Siralama } & \multirow{2}{*}{ Optimal $\lambda$} \\
\hline & & $\mathbf{0}$ & 0,1 & 0,2 & $\mathbf{0 , 3}$ & 0,4 & 0,5 & 0,6 & $\mathbf{0 , 7}$ & 0,8 & 0,9 & 1 & & \\
\hline \multirow{3}{*}{2010} & AlbarakaTürk Katılım Bankası A.Ş. & 0,797906 & 0,799879 & 0,801853 & 0,803826 & 0,805800 & 0,807773 & 0,809747 & 0,811720 & 0,813694 & 0,815667 & 0,817641 & 2 & \multirow{3}{*}{$\mathbf{0 , 5 5 8 0 3 9}$} \\
\hline & KuveytTürk Katılım Bankası A.Ş. & 0,776477 & 0,778360 & 0,780243 & 0,782126 & 0,784009 & 0,785892 & 0,787775 & 0,789658 & 0,791541 & 0,793423 & 0,795306 & 3 & \\
\hline & Türkiye Finans Katılım Bankası A.Ş. & 0,849018 & 0,850173 & 0,851328 & 0,852483 & 0,853638 & 0,854793 & 0,855947 & 0,857102 & 0,858257 & 0,859412 & 0,860567 & 1 & \\
\hline \multirow{3}{*}{2011} & AlbarakaTürk Katılım Bankası A.Ş. & 0,736615 & 0,738626 & 0,740638 & 0,742649 & 0,744660 & 0,746672 & 0,748683 & 0,750695 & 0,752706 & 0,754717 & 0,756729 & 3 & \multirow{3}{*}{0,542944} \\
\hline & KuveytTürk Katılım Bankası A.Ș. & 0,828091 & 0,830391 & 0,832691 & 0,834991 & 0,837291 & 0,839591 & 0,841891 & 0,844190 & 0,846490 & 0,848790 & 0,851090 & 2 & \\
\hline & Türkiye Finans Katılım Bankası A.Ş. & 0,870002 & 0,870515 & 0,871028 & 0,871540 & 0,872053 & 0,872566 & 0,873078 & 0,873591 & 0,874103 & 0,874616 & 0,875129 & 1 & \\
\hline \multirow{3}{*}{2012} & AlbarakaTürk Katılım Bankası A.Ş. & 0,698498 & 0,700742 & 0,702985 & 0,705229 & 0,707473 & 0,709717 & 0,711960 & 0,714204 & 0,716448 & 0,718691 & 0,720935 & 3 & \multirow{3}{*}{$\mathbf{0 , 5 3 6 4 8 3}$} \\
\hline & KuveytTürk Katılım Bankası A.Ş. & 0,737455 & 0,738985 & 0,740515 & 0,742045 & 0,743574 & 0,745104 & 0,746634 & 0,748164 & 0,749693 & 0,751223 & 0,752753 & 2 & \\
\hline & Türkiye Finans Katılım Bankası A.Ş. & 0,910674 & 0,911265 & 0,911856 & 0,912447 & 0,913038 & 0,913629 & 0,914220 & 0,914811 & 0,915402 & 0,915992 & 0,916583 & 1 & \\
\hline \multirow{3}{*}{2013} & AlbarakaTürk Katılım Bankası A.Ş. & 0,685498 & 0,688050 & 0,690602 & 0,693155 & 0,695707 & 0,698260 & 0,700812 & 0,703365 & 0,705917 & 0,708470 & 0,711022 & 3 & \multirow{3}{*}{0,541657} \\
\hline & KuveytTürk Katılım Bankası A.Ș. & 0,826336 & 0,828242 & 0,830148 & 0,832054 & 0,833960 & 0,835866 & 0,837772 & 0,839678 & 0,841583 & 0,843489 & 0,845395 & 2 & \\
\hline & Türkiye Finans Katılım Bankası A.Ş. & 0,915920 & 0,916539 & 0,917159 & 0,917779 & 0,918398 & 0,919018 & 0,919638 & 0,920257 & 0,920877 & 0,921497 & 0,922116 & 1 & \\
\hline \multirow{3}{*}{2014} & AlbarakaTürk Katılım Bankası A.Ş. & 0,531878 & 0,536972 & 0,542065 & 0,547158 & 0,552251 & 0,557344 & 0,562437 & 0,567530 & 0,572623 & 0,577716 & 0,582809 & 3 & \multirow{3}{*}{0,560781} \\
\hline & KuveytTürk Katılım Bankası A.Ş. & 0,832524 & 0,833847 & 0,835170 & 0,836493 & 0,837816 & 0,839139 & 0,840462 & 0,841785 & 0,843108 & 0,844431 & 0,845754 & 2 & \\
\hline & Türkiye Finans Katılım Bankası A.Ş. & 0,940422 & 0,940931 & 0,941439 & 0,941947 & 0,942456 & 0,942964 & 0,943472 & 0,943981 & 0,944489 & 0,944997 & 0,945506 & 1 & \\
\hline \multirow{3}{*}{2015} & AlbarakaTürk Katılım Bankası A.Ş. & 0,534329 & 0,539801 & 0,545273 & 0,550746 & 0,556218 & 0,561690 & 0,567162 & 0,572634 & 0,578107 & 0,583579 & 0,589051 & 3 & \multirow{3}{*}{0,563045} \\
\hline & KuveytTürk Katılım Bankası A.Ș. & 0,875974 & 0,877739 & 0,879503 & 0,881268 & 0,883032 & 0,884796 & 0,886561 & 0,888325 & 0,890090 & 0,891854 & 0,893619 & 2 & \\
\hline & Türkiye Finans Katılım Bankası A.Ş. & 0,935424 & 0,935894 & 0,936363 & 0,936833 & 0,937303 & 0,937773 & 0,938243 & 0,938713 & 0,939182 & 0,939652 & 0,940122 & 1 & \\
\hline \multirow{3}{*}{2016} & AlbarakaTürk Katılım Bankası A.Ș. & 0,513457 & 0,519487 & 0,525516 & 0,531546 & 0,537576 & 0,543605 & 0,549635 & 0,555665 & 0,561694 & 0,567724 & 0,573753 & 3 & \multirow{3}{*}{0,567844} \\
\hline & KuveytTürk Katılım Bankası A.Ş. & 0,894583 & 0,896461 & 0,898340 & 0,900219 & 0,902098 & 0,903976 & 0,905855 & 0,907734 & 0,909613 & 0,911491 & 0,913370 & 1 & \\
\hline & Türkiye Finans Katılım Bankası A.Ş. & 0,873230 & 0,873753 & 0,874275 & 0,874798 & 0,875320 & 0,875843 & 0,876365 & 0,876888 & 0,877410 & 0,877933 & 0,878455 & 2 & \\
\hline \multirow{3}{*}{2017} & AlbarakaTürk Katılım Bankası A.Ş. & 0,488696 & 0,494342 & 0,499987 & 0,505632 & 0,511278 & 0,516923 & 0,522568 & 0,528214 & 0,533859 & 0,539504 & 0,545149 & 3 & \multirow{3}{*}{$\mathbf{0 , 5 5 5 3 5 9}$} \\
\hline & KuveytTürk Katılım Bankası A.Ș. & 0,915691 & 0,917206 & 0,91872 & 0,920234 & 0,921749 & 0,923263 & 0,924778 & 0,926292 & 0,927806 & 0,929321 & 0,930835 & 1 & \\
\hline & Türkiye Finans Katılım Bankası A.Ş. & 0,77792 & 0,778936 & 0,779951 & 0,780967 & 0,781982 & 0,782998 & 0,784014 & 0,785029 & 0,786045 & 0,78706 & 0,788076 & 2 & \\
\hline
\end{tabular}


Tablo 10.'daki verilere göre $\lambda$ 'nın sıralamaya etkisi incelendiğinde, Qi sıralaması ile aynı sonuca ulaşılmış, herhangi bir sıra değişikliği olmamıştır. Ayrıca, yine Tablo 10.'da görülen optimal $\lambda$ değerlerinin tüm yıllar için 0.5 'e yakın oldukları görülmüş, performans sıralaması değişmemiştir.

\section{SONUÇ VE ÖNERÍLER}

$\mathrm{Bu}$ çalışmada Türk bankacılık sektörü içinde faaliyet gösteren katılım bankalarının performansları temel bilanço göstergeleri üzerinden ele alınarak, Entropi yöntemi ve WASPAS yöntemi aracılığıyla analiz edilmiştir. Ocak 2019 itibariyle Türkiye'de 5 adet katılım bankası faaliyet göstermektedir. Ancak Vakıf Katılım A.Ş. ve Ziraat Katılım Bankası A.Ş. 2015 yılında kurulup 2016 yılında faaliyetlerine başladıkları için analize dahil edilememiştir. Yapılan analizler aracılığıyla; 2010, 2011, 2012, 2013, 2014, ve 2015 y1lları için en iyi performansı gösteren katılım bankasının Türkiye Finans Katılım Bankası A.Ş.; 2016 ve 2017 yılları için en iyi performansı gösteren katılım bankasının ise KuvetTürk Katılım Bankası A.Ş. olduğu sonucuna ulaşılmıştır. Sonuçların optimal lambda değeri üzerinden yapılan WASPAS performans sıralamasında da değişmediği görülmüştür.

Katılım bankaları için yapılan performans sıralamasının seçilen kriterler açısından gerçekleştirildiği, kriterler ve analiz yapılan dönemler değiştirildiğinde sıralamanın da farklılaşabileceği unutulmamalıdır. Ural vd. (2018) tarafından "Kamu Bankalarında Performans Analizi: Entropi ve WASPAS Yöntemleri ile Bir Uygulama” başlıklı çalışmanın yapıldığg da göz önünde bulundurularak bundan sonrasında, özel sermayeli mevduat bankaları ile yatırım ve kalkınma banklarında entropi ve WASPAS yöntemleri aracılığıyla performans analizi ile ilgili çalışmaların yapılmasının hem literatüre hem de uygulayıcılara katkı sağlayacağı düşünülmektedir.

\section{KAYNAKLAR}

Akçakanat, Özen - Eren, Hande - Aksoy, Esra; Ömürbek, Vesile (2017), "Bankacılık Sektöründe Entropi ve WASPAS Yöntemleri ile Performans Değerlendirmesi”. Süleyman Demirel Üniversitesi İktisadi ve İdari Bilimler Fakültesi Dergisi, Cilt: 22, Sayı: 2, ss. 285-300.

Arslan, Emre Can (2017), Katılım Bankacılığı ve Türkiye Ekonomisine Katkıları. İstanbul: İstanbul Ticaret Üniversitesi Dış Ticaret Enstitüsü Working Paper Series.

Ayyıldız, Ertuğrul - Murat, Miraç (2017), "Türkiye'de Yer Alan Şehirlerin Eğitim Performanslarının Çok Kriterli Karar Verme Yöntemleri Kullanarak Belirlenmesi”, Kent Kültürü ve Yönetimi Hakemli Elektronik Dergi, Cilt: 10, Sayı: 2, ss. 255-267.

Bagočiusa, Vyganta - Zavadskasb, Kazimieras Edmundas - Turskis, Zenonas (2013), "MultiCriteria Selection of a Deep-Water Port in Klaipeda", Procedia Engineering, No: 57, pp. 144-148. 
Dejus, Titas - Antucheviciene, Jurgita (2013), “Assessment of Health and Safety Solutions at A Construction Site", Journal of Civil Engineering and Management, Vol: 19, No: 5, pp. 728-737.

Ergeç, Etem Hakan - Kaytancı, Bengül Gülümser - Toprak, Metin (2014), “Katılım Bankası Müşterilerinin Bankacılık Sistemi Kullanım Tercihleri: Mevduat Bankaları İçin İslami Bankacılık Penceresi”, Tüketici ve Tüketim Araştırmaları Dergisi, Cilt: 6, Sayı: 2, ss. 53-90.

Erol, Ece D. - Güneş, İsmet (2016), Katılım Bankacılığı (Ed. N. Oğuzhan Altay, C. Coşkun Küçüközmen, Mert Ural, Erhan Demireli), Bankacılığın El Kitabı, Ankara: Bankacılık Akademisi Yayınları.

Esmer, Yusuf - Bağcı, Haşim (2016), "Katılım Bankalarında Finansal Performans Analizi: Türkiye Örneği”, Mehmet Akif Ersoy Üniversitesi Sosyal Bilimler Enstitüsü Dergisi, Cilt: 8, Sayı: 15, ss. 17-30.

Ghorabaee, Mehdi Keshavar - Zavadskas, Edmundas Kazimieras - Amiri, Maghsoud, Ahmad Esmaeili (2016), "Multi-Criteria Evaluation of Green Suppliers Using an Extended WASPAS Method with Interval Type-2 Fuzzy Sets", Journal of Cleaner Production, No: 137, pp. 213-229.

Kalaycı, İrfan (2013), “Katılım Bankacılığı: Mali Kesimde Nasıl Bir Seçenek?”, Uluslararası Yönetim, İktisat ve İşletme Dergisi, Cilt: 9, Sayı: 19, ss. 51-74.

Karaca, Coşkun - Ulutaş, Alptekin (2018), "Entropi ve Waspas Yöntemleri Kullanılarak Türkiye İçin Uygun Yenilenebilir Enerji Kaynağının Seçimi”, Ege Akademik Bakış, Cilt: 18, Say1: 3, ss. 483-494.

Ömürbek, Nuri - Aksoy, Esra (2016), "Bir Petrol Şirketinin Çok Kriterli Karar Verme Teknikleri ile Performans Değerlendirmesi”, Süleyman Demirel Üniversitesi İktisadi ve İdari Bilimler Fakültesi Dergisi, Cilt: 21, Sayı: 3, ss. 723-756.

Özulucan, Abitter - Deran, Ali (2009), "Katılım Bankacılı̆̆ı ile Geleneksel Bankaların Bankacılık Hizmetleri ve Muhasebe Uygulamaları Açısından Karşılaştırılması”, Mustafa Kemal Üniversitesi Sosyal Bilimler Enstitüsü Dergisi, Cilt: 6, Say1: 11, ss. 85-108.

Pehlivan, Pınar (2016), “Türkiye'de Katılım Bankacılığı ve Bankacılık Sektöründeki Önemi”, Selçuk Üniversitesi İktisadi ve İdari Bilimler Fakültesi Sosyal Ekonomik Araştırmalar Dergisi, Cilt: 16, Sayı: 31, ss. 296-324.

TKBB, Türkiye Katılım Bankaları Birliği (2019). http://www.tkbb.org.tr (Erişim Tarihi: 2019).

Ural, Mert- Demireli, Erhan- Güler Özçalık, Sevinç (2018), “Kamu Bankalarında Performans Analizi: Entropi ve WASPAS Yöntemleri ile Bir Uygulama”, Pamukkale Üniversitesi Sosyal Bilimler Enstitüsü Dergisi, Say1: 31, ss. 129-141. 
